PET Imaging Studies in Drug Abuse Research

Joanna S. Fowler, Nora D. Volkow, Yu-Shin Ding, Jean Logan, Gene-Jack Wang

Brookhaven National Laboratory, Upton, NY 11973

Author Correspondence

Dr. Joanna S. Fowler

Chemistry Department, Bldg. 555

Brookhaven National Laboratory

Upton, NY 11973-5000

(631) 344-4365 telephone

(631) 344-7902 fax

fowler@bnl.gov 


\section{PET Imaging Studies in Drug Abuse Research}

\section{Joanna S. Fowler, Nora D. Volkow, Yu-Shin Ding, Jean Logan, Gene-Jack Wang Brookhaven National Laboratory, Upton, NY 11973}

There is overwhelming evidence that addiction is a disease of the brain (Leshner, 1997). Yet public perception that addiction is a reflection of moral weakness or a lack of willpower persists. The insidious consequence of this perception is that we lose sight of the fact that there are enormous medical consequences of addiction including the fact that a large fraction of the total deaths from cancer and heart disease are caused by smoking addiction. Ironically the medical school that educates physicians in addiction medicine and the cancer hospital that has a smoking cessation clinic are vanishingly rare and efforts at harm reduction are frequently met with a public indignation. Meanwhile the number of people addicted to substances is enormous and increasing particularly the addictions to cigarettcs and alcohol. It is particularly tragic that addiction usually begins in adolescence and becomes a chronic relapsing problem and there are basically no completely effective treatments. Clearly we need to understand how drugs of abuse affect the brain and we need to be creative in using this information to develop effective treatments.

Imaging technologies have played a major role in the conceptualization of addiction as a disease of the brain (Fowler et al., 1998a; Fowler et al., 1999a). New knowledge has been driven by advances in radiotracer design and chemistry and positron emission tomography (PET) instrumentation and the integration of these scientific tools with the tools of biochemistry, pharmacology and medicine. This topic cuts across the medical specialties of neurology, psychiatry, cancer and heart disease because of the high medical, social and economic toll that drugs of abuse, including and especially the legal drugs, cigarettes and alcohol, take on society. In this chapter we will begin by highlighting the important role that chemistry has played in making it possible to quantitatively image the movement of drugs as well as their effects on the human brain. This will be followed by highlights of PET studies of the acute effects of the 
psychostimulant drugs cocaine and methylphenidate (ritalin) and studies of the chronic effects of cocaine and of tobacco smoke on the human brain. This chapter concludes with the description of a study which uses brain imaging coupled with a specific pharmacological challenge to address the age-old question of why some people who experiment with drugs become addicted while others do not.

\section{The Importance of Chemistry}

The ability to isolate and monitor specific chemical changes in the human brain and to probe the consequences of chronic drug exposure depends on advances in radiotracer chemistry (Fowler et al., 1997). A broad look at some of the major radiotracers applied to studies of drugs of abuse (Figure 1) makes it possible to highlight the fundamental advances upon which they rest. Many of these go back several decades, but they are the workhorses of today's basic and clinical research.

Labeled Precursors: The excitation function for the ${ }^{20} \mathrm{Ne}\left(\ddot{\mathrm{d}, \alpha},{ }^{18} \mathrm{~F}\right.$ reaction coupled with $\left[{ }^{18} \mathrm{~F}\right] \mathrm{F}_{2}$ targets (Lambrecht and Wolf, 1973) and the excitation function for the ${ }^{18} \mathrm{O}(\mathrm{p}, \mathrm{n})^{18} \mathrm{~F}$ reaction (Ruth and Wolf, 1979) coupled with the development of oxygen-18-enriched targets (water and gas) (Firouzbakht et al., 1999) formed the groundwork for almost all of the fluorine-18 labeled tracers in use today (for a review see Kilbourn, 1990; Ding and Fowler, 1996). These include 2deoxy-2- $\left[{ }^{18} \mathrm{~F}\right]$ fluoro-D-glucose $\left({ }^{18} \mathrm{FDG}\right.$ ) (Ido et al., 1978; Hamacher et al., 1986, $\left[{ }^{18} \mathrm{~F}\right]$ fluoroDOPA (Firnau et al.,1986); $\left[{ }^{18} \mathrm{~F}\right]$ receptor and transporter binding tracers (Shiue et al., 1985) and $\left[{ }^{18} \mathrm{~F}\right]$ catecholamines (Ding et al., 1990). All of these reactions have become important scientific tools. The nucleophilic aromatic substitution made it possible to produce F-18 labeled aromatic compounds including those with electron-rich substituents in high specific activity and allowed the first tracer studies of F-18 labeled receptor and transporter binding tracers at subpharmacological doses (Attina et al., 1983; Ding et al., 1990).

The development of gas targets based on the ${ }^{14} \mathrm{~N}(\mathrm{p}, \alpha)^{11} \mathrm{C}$ reaction made the production of carbon-11 relatively straightforward (Christman et al., 1975). Rapid reproducible methods for 
making $\left[{ }^{11} \mathrm{C}\right]$ methyl iodide first by the wet chemical methods (Langstrom et al.,1976) and recently by the gas phase method (Larsen et al., 1995; Link et al., 1995) revolutionized tracer development and allowed the synthesis of many labeled compounds for measuring drug pharmacokinetics such as $\left[{ }^{11} \mathrm{C}\right]$ cocaine (Fowler et al., 1989) and $\left[{ }^{11} \mathrm{C}\right]$ methylphenidate (Ding et al., 1994) as well as $\left[{ }^{11} \mathrm{C}\right]$ raclopride, (Farde et al., 1986) the key radiotracer for measuring dopamine D2 receptor availability and drug-induced changes in dopamine concentration (Volkow et al., 1994).

Tracer Kinetics: It is widely appreciated that the application of tracer kinetics in the context of specific interventions (pharmacological, isotope, stereochemistry) is a key issue in being able to sensitively measure the availability of a specific molecular target (Mintun et al., 1984). The advantages and limitations of obtaining absolute concentrations of molecular targets and the confounding influence of changes in blood flow on kinetic terms which can be derived from a radiotracer study have generated much research and controversy. The advent of graphical methods first for irreversible systems with the Patlak Plot (Patlak et al., 1983) and then for reversible systems with the Logan Plot (Logan et al., 1990) has simplified kinetic analysis but at the same time there are pitfalls and each new tracer requires a fresh critical analysis of the factors which contribute to the moment-to-moment changes in radioactivity concentration. It is expected that this subject will continue to lie at the heart of our ability to make a critical assessment of the meaning of measurements. It was also during the last 20 years that measurement of the input function became an integral part of the study and that rapid and sometimes automated methods for making these measures were developed (Alexoff et al., 1995).

Mechanistic Studies: Because PET and single photon emission computed tomography (SPECT) measure photons and not chemical forms, mechanistic approaches are required to attach biochemical significance to the image. Most mechanistic studies are undertaken in small animals which are sacrificed at different times to obtain kinetics, tissue extraction and analysis to assess chemical form and pharmacological blockade to assess specificity. Translational research from animals to humans usually requires assuming that the same issues apply in humans. There 
are, however, mechanistic tools which have been applied in humans, including stereoselective binding when the tracer or drug contains a chiral center (Fowler et al., 1987; Ding et al., 1997), pharmacological blockade when safety and toxicity permit (Fowler et al., 1996a) the use of deuterium isotope effects (when there is a labile $\mathrm{C}-\mathrm{H}$ bond in a rate-limiting step) (Fowler et al., 1988, 1995) and labeling in different positions (Halldin et al., 1989; Gatley et al., 1994). Additionally other neuroscience tools such as microdialysis have been combined with imaging to assess the relationship between changes in radiotracer concentration as measured by PET and neurotransmitter release (Breier et al., 1997; Dewey et al., 1999). In the near future, the development and use of small animal PET instruments promises to streamline the process and allow imaging of genetically modified animals (Chatziioannou et al., 1999; Jeavons et al.,1999).

\section{PET Studies of Psychostimulants}

\section{Cocaine}

(-)-Cocaine is a powerful stimulant isolated from erythroxylon coca. It binds to dopamine, norepinephrine and serotonin transporters with micromolar to submicromolar affinity (Ritz et al., 1987). Cocaine's behavioral properties have been generally attributed to its ability to block the dopamine transporter (DAT) causing the elevation of synaptic dopamine (DA) in the nucleus accumbens. Autoradiographic studies of cocaine binding in vitro in human and primate brain sections have been carried out with $\left[{ }^{3} \mathrm{H}\right]$ cocaine (Biegon et al., 1992) and $\left[{ }^{3} \mathrm{H}\right]$ WIN 35428 (Madras et al., 1989). The highest density of binding sites for cocaine is in the basal ganglia, the brain region containing the highest density of dopamine terminals, with minimal binding in other brain regions. Similar results were obtained in in vivo studies in the mouse with [ $\left.{ }^{3} \mathrm{H}\right]$ WIN 35428 (Scheffel et al., 1991). Cocaine also is a potent local anesthetic (Ritchie and Green, 1990). Though the multiple direct and indirect interactions of cocaine with tissue exists complicating the association of its behavioral and addictive properties with a specific molecular target, there is mounting evidence that the binding of cocaine to the DAT with its rapid ensuing elevation of dopamine dominates its behavioral effects in humans (Volkow et al., 1999b). 
Cocaine metabolism proceeds by three major initial transformations: cleavage of the benzoyl ester to give ecgonine methyl ester; cleavage of the methyl ester to give benzoyl ecgonine and oxidative $\mathrm{N}$-demethylation to give norcocaine (Kloss et al., 1984). In humans, the predominant pathway is its metabolism by butyrylcholinesterase to form ecgonine methyl ester. The formation of norcocaine which is also pharmacologically active and the only cocaine metabolite which can enter the brain is a minor pathway in humans (Misra et al., 1975) (Figure 2). The behavior of cocaine in the brain and peripheral organs and its effects on peripheral organs have been studied with PET. In addition, the pharmacokinetics of cocaine and another stimulant drug methylphenidate have been compared.

Brain Pharmacokinetics: At tracer doses, $\left[\mathrm{N}-{ }^{11} \mathrm{C}\right.$-methyl $]$ cocaine has a very high and rapid uptake and clearance in the human striatum and clearance half-time of about 20 minutes (Fowler et al., 1989). Inhibition of norepinephrine transporter with desipramine did not change $\left[{ }^{11} \mathrm{C}\right]$ cocaine binding relative to a baseline scan indicating that the contribution of norepinephrine transporters to the PET image is negligible. Though the low specific to non-specific binding ratio of $\left[{ }^{11} \mathrm{C}\right]$ cocaine as well as its rapid clearance have been limitations to the identification of cocaine binding sites in brain regions other than the striatum, recently $\left[{ }^{11} \mathrm{C}\right]$ cocaine brain images from 17 normal healthy subjects were averaged to increase the signal-to-noise ratio and to map the binding of this drug in non-striatal areas. Brain regions clustered into high cocaine binding (putamen $>$ accumbens $>$ caudate), moderate binding (thalamus $>$ precuneus $>$ posterior cingulate gyrus>amygdala, hippocampus and temporal pole) and low cocaine binding groups (orbital cortex, precentral gyrus and cerebellum) (Telang et al., 1999).

The temporal relationship between the kinetics of cocaine in the human brain and its behavioral effects was recently studied (Volkow et al., 1997a). In this study the time course for the uptake and clearance of $\left[{ }^{11} \mathrm{C}\right]$ cocaine co-administered intravenously with behaviorally active doses of unlabeled cocaine was measured in 17 current cocaine abusers. Peak uptake occurred at 5-10 minutes and the half-time of clearance from peak being about 12 minutes (Figure 3). Selfreports of the "high' during the PET study almost perfectly paralleled the time course of cocaine 
in the striatum for the initial 20 minutes though the high dissipates more rapidly than the levels of $\left[{ }^{11} \mathrm{C}\right]$ cocaine at later times. The rapid uptake and high concentration of cocaine at dopamine terminals are key contributors to its powerful reinforcing properties. It is well known that the shorter the time between the administration of a drug and its behavioral effects, the more intense the behavioral stimulation (Balster and Schuster, 1973).

Cocaine exists in two enantiomers, (-)-cocaine which is the natural product and (+)cocaine which is produced synthetically. Only ${ }^{\cdot}(-)$-cocaine is behaviorally active. It also has a higher affinity for the DAT (Ritz et al., 1987), a property that has been used to support the hypothesis that there is an association between cocaine's behavioral effects and binding to the DAT (Spealman et al., 1983). However, in PET studies in the baboon with $(+)-\left[{ }^{11} \mathrm{C}\right]$-cocaine, no brain uptake was detected due to its very rapid metabolism by plasma butyrylcholinesterase (Gatley et al., 1990, 1991) (Figure 4). Within 30 seconds after injection, ( + ) $-\left[{ }^{11} C\right]$ cocaine could not be detected in the blood. Hydrolysis was blocked by physostigmine implicating serum butyrylcholinesterase. Comparative studies in vivo and in vitro showed that the hydrolysis of $(+)$-cocaine is at least 1000 times faster than $(-)$-cocaine. This study revealed for the first time that even though its affinity at the DAT is much lower than that of $(-)$-cocaine, the lack of brain uptake is an overriding factor in its lack of behavioral activity. In fact $(+)$-cocaine is a poor choice as a control in behavioral studies. This study illustrates the importance of assessing the metabolism of a drug as well as its receptor binding properties in establishing a mechanistic link between a drug and its behavioral and therapeutic properties.

Distribution and kinetics in peripheral organs: Cocaine's effects on monoamine concentration in the brain may be mirrored in its effects on monoamine concentration and regulation in the peripheral organs. The short term distribution of $\left[{ }^{11} \mathrm{C}\right]$ cocaine and its labeled metabolites (at tracer doses) was measured in peripheral organs in 14 healthy male subjects (Volkow et al., 1992b). The rate of uptake and clearance varied with different organs. Peak uptake occurred in heart and kidneys at 2-3 minutes, in the adrenals at 7-9 minutes and in the liver at 10-15 minutes. There was no uptake in the lungs. The half-times for clearance from the 
peak uptakes were 10 minutes for the heart and kidneys and 22 minutes for the adrenals. Liver radioactivity plateaued at 10-15 minutes and remained constant for 40 minutes. Though no assessment of the chemical form or binding specificity was made in these studies, the radioactivity in organs with peak uptake at early times (heart, adrenals and kidneys) probably is in the chemical form of cocaine itself while that which slowly accumulates probably reflect labeled metabolites of cocaine.

The high uptake of cocaine in the human heart is of potential medical importance because cardiotoxocity is a major medical complication in cocaine abuse (Kloner et al., 1992). Cocaine's peripheral actions involve both direct effects on the myocardium (Polkis et al., 1987) and indirect effects brought about by release of catecholamines from the adrenal glands (Chiueh and Kopin, 1978). The high uptake of cocaine in the heart as demonstrated by PET is consistent with high levels of cocaine in the myocardium of individuals who have died of cocaine overdose (Polkis et al., 1987). The molecular target(s) for cocaine accumulation in the heart were investigated in the baboon (Fowler et al., 1994). Surprisingly, cocaine binding in the heart cannot be blocked by desipramine, tomoxetine, nomifensine, benztropine or cocaine itself. However, cocaine exposure has a prolonged effect of the function of the norepinephrine transporter (the major neuronal element responsible for terminating the action of norepinephrine). PET studies in the baboon and in the dog using 6- $\left[{ }^{18} \mathrm{~F}\right]$ fluoronorepinephrine (Ding et al., 1991) and $\left[{ }^{11} \mathrm{C}\right]$ hydroxyephedrine respectively have revealed that cocaine blocks norepinephrine transporter function long after the cocaine has cleared from the heart (Fowler et al., 1994; Melon et al., 1994). More specifically, in the baboon heart norepinephrine transporter function is inhibited with only $48 \%$ of norepinephrine reuptake recovered by 78 minutes after cocaine administration (Fowler et al., 1994). Similar long term inhibition of norepinephrine transporter function in chronic cocaine users was also evident using $\left[{ }^{11} \mathrm{C}\right]$ hydroxyephedrine (Melon et al., 1997) suggesting prolonged reduction of norepinephrine reuptake and storage capacity. This may account for some of the reports of cocaine-induced cardiotoxicity in athletes who use cocaine. Exercise would cause a release of norepinephrine which stimulates the adrenergic system. In the 
normal healthy individual, this would be regulated through the norepinephrine transporter whereas in the cocaine user, this protective mechanism would be disabled.

\section{Comparative studies of cocaine and methylphenidate (Ritalin)}

Methylphenidate (MP), is a psychostimulant drug used in children for the treatment of Attention Deficit Hyperactivity Disorder (ADHD) (Carrey et al., 1996). The therapeutic properties of MP appear to have been postulated to reside in its ability to block the reuptake of dopamine thereby increasing the concentration of dopamine in the synapse.

Methylphenidate is marketed as a mixture of the $d$-threo and the 1-threo enantiomers. Yet the biological activity of thesc enantiomers is significantly higher than that of the 1-threo enantiomer (eudismic ratio=10) (Patrick et al., 1987). Both $d$-threo and 1-threo-methylphenidate were labeled with carbon-11 (Ding et al., 1994) and compared directly in the human brain with PET (Ding et al., 1997). As expected the $d$-threo enantiomer binds in the striatum while the 1 threo enantiomer clears and shows no specific retention.

Though MP has been in used for 40 years, it was not until 1999, that the mechanistic framework accounting for why an increase in brain dopamine is therapeutic in the ADHD individual was revealed. SPECT measurements comparing dopamine transporter availability for ADHD adults and age-matched comparison subjects, showed a significant elevation in the DAT in the ADHD subjects (Dougherty et al., 1999; Krause et al., 2000). Because the DAT are responsible for clearing dopamine from the synapse, an excess of the DAT molecules would be predicted to lower synaptic dopamine creating a deficiency which is restored when the DAT is blocked by methylphenidate. The elevation of synaptic dopamine after oral methylphenidate administration has recently been verified in humans (Volkow et al., in press).

One of the intriguing issues associated with the therapeutic use of MP, is that it blocks the DAT with a similar affinity to that of cocaine (Volkow et al., 1995). Since blockade of the DAT is associated with the reinforcing effects of cocaine (Ritz et al., 1987) many have expressed concern regarding the potential abuse liability of MP (Parran and Jasinski, 1991). Though MP is 
self-administered by laboratory animals (Johanson et al., 1975; Bergman et al., 1989) and abused in humans (Parran and Jasinski, 1991), the abuse of MP is much more limited than that of cocaine (National Institute on Drug Abuse, 1995). Also MP abuse occurs predominantly via the intravenous and not the oral route of administration (Parran and Jasinski, 1991).

Pharmacokinetics: In order to understand the similarities and differences between cocaine and methylphenidate, the pharmacokinetics and the degree to which they block DAT at behavioral and therapeutic doses were compared in the human brain with PET. Each drug was labeled with carbon-11. The position of the label in the N-methyl group for cocaine and the Omethyl group for methylphenidate were chosen to remove ambiguity as to whether the labeled drug or its labeled metabolites are visualized in the brain. [The only metabolite of cocaine which can enter the brain is norcocaine ( $\mathrm{N}$-demethyl) and this would not be labeled when $\left[\mathrm{N}-{ }^{11} \mathrm{C}\right.$ methyl]cocaine is used. Similarly, ritalinic acid, the major metabolite of methylphenidate would not be labeled and also does not enter the brain.]

When administered intravenously, both $\left[{ }^{11} \mathrm{C}\right]$ cocaine and $\left[{ }^{11} \mathrm{C}\right]$ methylphenidate reached peak concentration in the brain very rapidly (peak uptake for cocaine was 4-6 minutes and for MP it was 8-10 minutes) when administered intravenously. However, their clearance rates differed markedly; $\left[{ }^{11} \mathrm{C}\right]$ cocaine clearance was much faster than that of MP $\left(\mathrm{t}_{1 / 2}: 20\right.$ versus 90 minutes). In the case of cocaine, its rapid uptake and clearance paralleled the short-lived, selfreports of "high" induced by the drug (Volkow et al., 1995). In the case of MP, the fast uptake of the drug paralleled only the ascending limb of the time course for the "high", which returned to baseline rapidly even though MP had not cleared from brain (Volkow et al., 1996). The rapid uptake of intravenously administered $\left[{ }^{11} \mathrm{C}\right]$ cocaine and $\left[{ }^{11} \mathrm{C}\right]$ methylphenidate in the brain contrasts to the slow brain uptake of orally administered $\left[{ }^{11} \mathrm{C}\right]$ methylphenidate which takes about 60 minutes to reach peak uptake in the brain (Volkow et al., 1998) (Figure 5). It has been postulated that this slow brain uptake is the reason why MP does not induce a "high" when administered orally since the rapidity at which drugs of abuse exert their effects has been shown to be crucial in their reinforcing effects (Balster et al., 1973). 
Dopamine Transporter Occupancy: As part of the investigation into factors which may account for differences between cocaine and methylphenidate; a comparison of their relative occupancies of the DAT at pharmacologically effective doses was also made. Using $\left[{ }^{11} \mathrm{C}\right]$ cocaine as a tracer for DAT occupancy, it was found that an intravenous dose of $0.075 \mathrm{mg} / \mathrm{kg}$ of MP was required to occupy $50 \%$ of DAT (Volkow et al., 1996). This is in the same range as intravenously administered cocaine which occupies $50 \%$ of the DAT at a dose of $0.13 \mathrm{mg} / \mathrm{kg}$. When MP was given orally, a dose of $0.25 \mathrm{mg} / \mathrm{kg}$ was required to occupy $50 \%$ of the DAT (Volkow et al., 1998) (Figure 6). The latter dose is within the range of therapeutic doses used in the treatment of ADHD. In spite of the fact that oral MP induced levels of DAT blockade similar to those induced by reinforcing doses of cocaine, it did not induce a "high". These comparative PET studies draw a compelling picture of the importance of drug pharmacokinetics and route of administration as major contributing factors in drug abuse versus drug therapy. Indeed, when MP is given intravenously, it also produces a "high" that most cocaine abusers cannot distinguish from that produced by cocaine (Volkow et al., 1996). Such studies measuring pharmacokinetics and DAT occupancy provide important knowledge in the continuing effort to develop a pharmacologic strategy for treating cocaine abuse (O’Brien et al., 1997).

\section{Imaging the Cocaine Abuser's Brain}

Dopamine function in cocaine abusers: It has been postulated that the chronic blockade of the dopamine transporter by cocaine produces changes in the dopamine system which lead to the compulsive use of the drug. This has been investigated with PET in cocaine abusers using multiple tracers to study glucose metabolism, dopamine D2 receptor availability and dopamine responsivity. In recently detoxified cocaine abusers ( $<1$ week) brain glucose metabolism was significantly higher in orbitofrontal cortex and in striatum than in healthy non-abusing controls (Volkow et al., 1991). Brain metabolism was highest in subjects tested during the initial 72 hours after withdrawal and cocaine abusers who had the highest metabolic values in orbitofrontal cortex and striatum also had the highest subjective ratings for craving. In contrast, cocaine 
abusers tested between 1 and 4 months of detoxification showed significant reductions in metabolic activity in prefrontal cortex, orbitofrontal cortex, temporal cortex and cingulate gyrus (Volkow et al., 1992a).

${ }^{18} \mathrm{FDG}$ measures brain glucose metabolism which, in part, reflects the energy required to restore membrane potentials (Schwartz et al., 1976). For this reason, regional abnormalites in glucose metabolism which are associated with the action of a particular drug can potentially provide mechanistic information on specific neurotransmitters which are associated with these changes. In the case of cocaine, low metabolism in the orbitofrontal cortex and in the cingulate gyrus strongly implicates the brain dopamine system since these are the cortical projections of the mid-brain dopamine cell bodies. In order to test the hypothesis that changes in glucose metabolism are associated with the brain dopamine system, dopamine D2 receptor availability was also measured in the same subjects with $\left[{ }^{18} \mathrm{~F}\right] \mathrm{N}$-methylspiroperidol. These studies revealed decreases in dopamine D2 receptor availability in cocaine abusers relative to normal subjects (Volkow et al., 1990). Furthermore levels of dopamine D2 receptors correlated significantly with measures of metabolic activity in orbitofrontal cortex, cingulate gyrus and prefrontal cortex (Volkow et al., 1993). Lower values for D2 receptor concentration were associated with lower metabolism in these brain regions and these reductions in dopamine D2 receptor availability persisted in the follow-up studies performed 3 months after completing the inpatient detoxification program. This observation led to the postulate that DA disruption of the orbitofrontal cortex may be one of the mechanisms underlying the loss of control by the cocaine abuser during a binge or when exposed to cocaine and/or cocaine related cues (Volkow and Fowler, 2000). Thus DA involvement in addiction may be mediated by its interactions with frontal circuits involved in the control of repetitive and impulsive behaviors. Findings from these studies have served to demonstrate that addicted individuals have neurochemical changes in their brains that may underlie their inability to control their impulses to take the drug and may explain relapse. This notion has been reinforced by recent PET studies with $\left[{ }^{11} \mathrm{C}\right]$ raclopride showing that cocaine abusers when challenged with an acute intravenous dose of the 
psychostimulant drug methylphenidate, release significantly less dopamine and have a correspondingly lower behavioral response to the drug than normal subjects (Volkow et al., 1997b). This finding supports the postulate that cocaine abusers have decreased dopamine function (Dackis and Gold, 1985).

\section{Imaging the Smoker's Brain}

The effects of nicotine and tobacco smoke on the human brain have been studied using a variety of imaging techniques (Domino, 1995; Stein et al., 1998). Research has focussed almost entirely on nicotine and there is considerable effort currently being devoted to the development of radioligands for imaging brain nicotinic receptors both for studies of addiction and as scientific tools in drug research and development (Ding et al., 2000a-c; Sihver et al., 2000). There is now no doubt that nicotine is the addictive component of cigarette smoke. It is also appreciated that carbon monoxide from smoke is a major players in cardiac disease associated with smoking (Benowitz, 1997) and that tars contain the carcinogens which result in the high incidence of lung and upper airway cancers associated with smoking. However, tobacco smoke contains several thousand chemical compounds and some of these may also contributc to some of its pharmacological effects. Our studies have focussed on the cffect of tobacco smoke exposure on the enzyme monoamine oxidase (MAO).

Monoamine oxidase occurs in most cells in most species (Singer et al., 1995). It is located in the outer mitochondrial membrane and oxidizes amines from both endogenous and exogenous sources. There are two subtypes, MAO A and MAO B which have different substrate and inhibitor specificities. Peripheral MAO plays a protective role in that it breaks down vasoactive amines like tyramine which are present in certain foods and fermented beverages (Anderson et al., 1993). Brain MAO occurs in both neurons and glial cells and plays a role in the regulation of neurotransmitters, the MAO A subtype breaking down norepinephrine and serotonin and the MAO B subtype breaking down phenethylamine. Both subtypes appear to break down dopamine. 
It has been known for many years that platelet MAO is significantly lower in smokers (Oreland et al., 1981). However, MAO levels are normal in smokers who quit indicating that low MAO B is a pharmacological effect of the smoke rather than a biological characteristic of smokers (Norman et al., 1987). Similar to the findings of low platelet MAO in smokers, PET studies of normal volunteers with $\left[{ }^{11} \mathrm{C}\right] \mathrm{L}$-deprenyl- $\mathrm{D}_{2}$ (Fowler et al., 1995) revealed that cigarette smokers had very low brain MAO B while former smokers have normal levels (Fowler et al., 1996b). PET studies measuring MAO A with $\left[{ }^{11} \mathrm{C}\right]$ clorgyline (Fowler et al., 1987). showed that smokers also have reduced MAO A (Fowler et al., 1996a). Inhibition is partial, with average reductions of $30 \%$ and $40 \%$ being observed for MAO A and B respectively. This observation raises intriguing questions as to whether MAO inhibilion by smoke may contribute to some of the behavioral and epidemiological features of smoking including the decreased risk of Parkinson's disease in smokers (Morens et al., 1995) and an increased rate of smoking in depression (Glassman et al., 1990) and in addictions to other substances (Henningfield et al., 1990) and a general prevalence of smoking in psychiatric ilnesses (Hughes et al., 1986). Reductions in MAO A and B, in principle, could spare neurotransmitters from oxidation and reduce the production of hydrogen peroxide, a byproduct of MAO catalyzed oxidation (Cohen and Kesler, 1999). MAO inhibition may act synergistically with the dopamine-releasing properties of drugs of abuse by protecting dopamine from metabolism.

Nicotine does not inhibit platelet MAO when it is present in the concentrations normally achieved during smoking (Oreland et al., 1981) nor does it inhibit MAO B in the living baboon when administered intravenously (Fowler et al., 1998b). Recently the fractionation of extracts from flue-cured tobacco leaves led to the isolation of a competitive inhibitor of human MAO A $(\mathrm{K}(\mathrm{i})=3 \mu \mathrm{M})$ and MAO B $(\mathrm{K}(\mathrm{i})=6 \mu \mathrm{M})$, the structure of which could be assigned as $2,3,6$ trimethylbenzoquinone, by classical spectroscopic analysis and confirmed by synthesis (Khalil et al., 2000). This information may help to provide insights into some aspects of the pharmacology and toxicology of tobacco products. 
While tobacco smokers have an average of $40 \%$ lower values of brain MAO B than nonsmokers and former smokers, the degree of MAO B inhibition is quite variable between subjects, ranging between 17 and $67 \%$. The variability in the level of inhibition between the smokers was not accounted for by the smoking duration (average $24 \pm 13.5$ years) or the frequency (average $1 \pm 0.27$ packs/day). Because the time interval between the PET MAO B measurements and the last cigarette varied between subjects (range 1.7-12 hours), a study was undertaken to determine whether MAO B activity recovered measurably after an overnight smoke-free interval (Fowler et al., 2000). Brain MAO B was measured using PET and [ $\left.{ }^{11} C\right] L-d e p r e n y l-D_{2}$ in six smokers who were scanned twice, once at 11.3 hours (baseline) after last cigarette and once at 10 minutes after smoking. Brain MAO B levels did not differ between baseline and after smoking as determined using a three compartment model (Logan et al., 2000) (Figure 7A).

Another aspect of the pharmacodynamic relationship between tobacco smoke exposure and MAO inhibition relates to whether MAO inhibition can be detected after a single cigarette. For this purpose brain MAO B was measured in a group of 8 non-smokers at baseline and immediately after smoking a single cigarette using $\left[{ }^{11} \mathrm{C}\right] \mathrm{L}$-deprenyl- $\mathrm{D}_{2}$ and PET. Eight normal healthy non-smokers ( $35 \pm 11$ years) received two PET studies 2 hours apart with $\left[{ }^{11} \mathrm{C}\right] \mathrm{L}$ deprenyl- $\mathrm{D}_{2}$, one at baseline and the second 5-10 minutes after the subject has smoked a single cigarette (Fowler et al., 1999b). Plasma nicotine and expired carbon monoxide (CO) were measured prior to smoking and 10 minutes after smoking completion as an index of tobacco smoke exposure. A 3-compartment model was used to calculate $\lambda k_{3}$, a model term proportional to MAO B and $K_{1}$ for the plasma-to-brain transfer constant which is related to brain blood flow. The average $\lambda k_{3}$ and $K_{1}$ for different brain regions did not differ significantly between baseline and smoking (Figure 7B). These results indicate that the reduction in MAO B in smokers occurs gradually and requires chronic tobacco smoke exposure.

The observation that smokers have reduced brain MAO A and B reinforces the importance of reporting smoking status in clinical studies and the need to reevaluate reports that low platelet MAO B is a biological marker in clinical populations where the rate of smoking is 
high such as schizophrenia (Lidberg et al., 1985). In fact, normal platelet MAO was recently reported in non-smoking patients with schizophrenia (Simpson et al., 1999).

Smoking remains a major public health problem. Yet advances in treating smoking addiction hinge on characterizing both the neuropharmacological effects of tobacco smoke and factors accounting for individual variability in smoking toxicity. Along this line recent studies reporting the use of the reversible MAO A inhibitor moclobemide (Berlin et al.,1995a,b) and the combination of nicotine and L-deprenyl (Brauer et al., 2000) as smoking cessation treatments is an important step based on the knowledge that the addictive and toxic effects of tobacco smoke are complex and go beyond the effects of nicotine alone.

\section{Vulnerability}

The questions of why some people who experiment with drugs become addicted while others do not is an intriguing one. One of the hypotheses is that there are individual genetic factors which make some individuals more vulnerable to addiction. The "reward deficiency hypothesis" postulates that addictive behaviors, both pharmacological and non-pharmacological (gambling, for example) emerge as a result of understimulation of reward circuits with the drug taking or other behavior being used to stimulate these reward circuits. Indeed a variant on the dopamine $\mathrm{D} 2$ receptor (the Taq1 $\mathrm{A}_{1}$ allele) has been reported to occur more frequently in individuals with abnormal appetitive behaviors (Blum et al., 1996).

During our measures of dopamine receptor availability in cocaine abusers and in comparison subjects it was evident that there is enormous variability among individuals. Though cocaine abusers as a group have significant decrements in dopamine D2 receptors, there is considerable overlap in values with normal individuals (Volkow et al., 1999b). The great variability among individuals inspired a study designed to examine whether individuals with low dopamine receptor availability would react differently to a challenge with a stimulant drug (methylphenidate) than individuals with high dopamine receptor availability. It was predicted that individuals with low dopamine receptor levels would find methylphenidate more pleasurable 
than those with high receptor levels. This proved to be the case. Low receptor level individuals found methylphenidate pleasant while, on average, high receptor level individuals found it unpleasant (Figure 8). This supports the notion that individuals with low dopamine receptors may have an understimulated reward system and as a result they perceive a pleasureable sensation when subjected to a drug-induced elevation in dopamine. It follows that if an individual who takes a drug and finds it pleasant is more likely to repeat the behavior.

\section{Summary}

Over the past 25 years radiotracers for many of the major molecular targets of drugs of abuse have been synthesized, characterized pharmacologically, their kinetics have been modeled and they have been used to address medical questions directly in the relevant clinical population. Already neuroimaging studies of the pharmacokinetics and pharmaocdynamics of abused substances have started to document mechanisms of reinforcement and to delineate neurochemical changes in the brain of the addicted subject. Though these findings are still of a preliminary nature they indicate that imaging has enormous value in the area of substance abuse including: (1) the direct assessment of the behavior of drugs of abuse in the human brain. This is relevant both because drug pharmacokinetics and pharmacodynamics may vary across animal species. It also enables the assessment of drug behavior directly in the drug addict; (2) Because imaging studies are done in awake human subjects, PET imaging allows a determination of the relation between behavior and regional brain effects both in neurotransmitters as well as in function as assessed with measures of glucose metabolism or cerebral blood flow. Studies can also be done to assess the relation between pharmacokinetics of a given drug and the time course of its pharmacological effects; (3) Serial imaging studies can be performed in the same subject allowing an evaluation of the effects of drug withdrawal or drug treatment; (4) Neurochemical and functional changes can be viewed from many perspectives directly in the addicted individual; (5) Application of new knowledge in the development and assessment of new therapeutic interventions. 
Acknowledgment: This research was carried out at Brookhaven National Laboratory under contract DE-AC02-98CH10886 and with the U. S. Department of Energy and supported by its Office of Biological and Environmental Research and also by the National Institutes of Health (National Institute on Drug Abuse and National Institutes of Neurological Diseases and Stroke). 
Figure Captions:

Figure 1. Structures of some of the radiotracers and labeled drugs used in the study of drugs of abuse.

Figure 2. Major metabolic pathways for cocaine.

Figure 3. $\left[{ }^{11} \mathrm{C}\right]$ Cocaine time course in the striatum of a current cocaine abuser showing the congruence of cocaine binding and the behavioral "high." The dose of unlabeled cocaine (0.6 $\mathrm{mg} / \mathrm{kg}$ ) was co-administered intravenously with $\left[{ }^{11} \mathrm{C}\right]$ cocaine (Volkow et al., 1997a). For comparison purposes, values are expressed as percent from peak value.

Figure 4. Time-activity curves for $\left.(-)-{ }^{11} \mathrm{C}\right]$ cocaine and $(+)-\left[{ }^{11} \mathrm{C}\right]$ cocaine in the baboon brain. Note the absence of $\mathrm{C}-11$ uptake with $(+)-\left[{ }^{11} \mathrm{C}\right]$ cocaine due to rapid metabolism by serum butyrylcholinesterase (Gatley et al., 1990).

Figure 5. Time-activity curve for $\left[{ }^{11} \mathrm{C}\right]$ cocaine in the human striatum after intravenous injection (left panel) compared to the time-activity curve for $\left[{ }^{11} \mathrm{C}\right]$ methylphenidate administered orally in the baboon striatum (right panel) (Volkow et al., 1997a, 1998). Note that the rate of brain uptake for cocaine administered intravenously is very rapid in contrast to the rate of uptake of methylphenidate administered orally. Though both drugs bind to the dopamine transporter and occupy $>50 \%$ of the dopamine transporters at behaviorally active doses, it is likely that the difference in rate of uptake between the intravenous and oral routes accounts for the striking different effects of intravenous cocaine and oral methylphenidate.

Figure 6. Comparison of dopamine transporter occupancy by cocaine administered intravenously and methylphenidate administered orally. Note the similarity between the doses required to occupy $50 \%$ of the dopamine transporters for each of the drugs. Dopamine transporter occupancy was measured with [ ${ }^{11}$ C]cocaine and PET (Volkow et al., 1997, 1998). 
Figure 7. Bar graphs showing that smoking a single cigarette does not produce a measureable inhibition of MAO B in different brain regions (left panel) and that an overnight cigarette abstinence does not lead to a measureable recovery of MAO B (right panel). These two studies were done in non-smokers (Fowler et al., 1999b) and smokers (Fowler et al., 2000) respectively. These studies show that brain MAO B inhibition in smokers requires chronic exposure and that the recovery of brain MAO B is slow. Studies were done with [ $\left.{ }^{11} \mathrm{C}\right] \mathrm{L}$-deprenyl- $\mathrm{D}_{2}$ and PET. Figure 8. Comparison of dopamine D2 receptor levels in normal subjects who were also tested with a drug challenge of intravenous methylphenidate. On average, those who found methylphenidate pleasant had lower dopamine D2 receptor levels and those who found it unpleasant had higher dopamine receptor levels. Two of the subjects had a neutral response to the drug. Dopamine D2 receptor levels were measured with $\left[{ }^{11} \mathrm{C}\right]$ raclopride and PET (Volkow et al., 1999b). 
References

Alexoff DL, Shea C, Fowler JS, King P, Gatley SJ, Schlyer DJ, and Wolf AP (1995) Plasma input function determination for PET using a commercial laboratory robot. Nuclear Medicine and Biology 22, 893-904.

Anderson MC, Hasan F, McCrodden JF, and Tipton KF (1993) Monoamine oxidase inhibitors and the cheese effect. Neurochemical Research 18, 1145-1149.

Attina M, Cacace F, and Wolf AP (1983) Displacement of nitro group by ${ }^{18} \mathrm{~F}$-fluoride ion. A new route to high specific activity aryl fluorides. Journal of the Chemical Society, Chemical Communication, 107-109.

Balster RL and Schuster CR (1973) Fixed interval schedule of cocaine reinforcement: Effect of dose and infusion duration. Journal of Experimental and Analytical Behavior 20; 119129.

Benowitz NL (1997) The role of nicotine in smoking-related cardiovascular disease. Preventive Medicine 26, 412-417.

Bergman J, Madras B, Johnson SE, and Spealman RD (1989) Effects of cocaine and related drugs in nonhuman primates. III. Self administration by squirrel monkeys. Journal of Pharmacology and Experimental Therapy 251, 150-155.

Berlin I, Saïd S, Spreux Varoquaux O, Launay JM, Olivares R, Millet V, Lecrubier Y, and Puech AJ (1995a) A reversible monoamine oxidase A inhibitor (moclobemide) facilitates smoking cessation and abstinence in heavy, dependent smokers. Clinical Pharmacology and Therapy 58,4, 444-52.

Berlin I, Said S, Spreux-Varocuax O, Olivares R, Launay J-M, and Puech A (1995b) Monoamine oxidase A and B in heavy smokers. Biological Psychiatry 33, 756-761.

Biegon A, Dillon K, Volkow ND, Hitzemann RJ, Fowler JS and Wolf AP (1992) Quantitative autoradiography of cocaine binding sites in human brain postmortem. Synapse 10, 126130. 
Blum K, Cull JG, Braverman ER and Comings DE (1996) Reward deficiency syndrome. American Scientist 84, 145.

Brauer LH, Paxton DA, and Rose JE (2000) Selegiline and transdermal nicotine for smoking cessation. Presented at the 6th Annual Meeting of the Society for Research on Nicotine and Tobacco, February 18-20, Arlington, VA.

Breier A, Su TP, Saunders R, Carson RE, Kolachana BS, de Bartolomeis A, Weinberger DR, Weisenfeld N, Malhotra AK, Eckelman WC, and Pickar D (1997) Schizophrenia is associated with elevated amphetamine-induced synaptic dopamine concentrations: evidence from a novel positron emission tomography method. Proceedings of the National Academy of Science USA 94, 2569-2574.

Carrey NJ, Wiggins DM, and Milin RP (1996) Pharmacological treatment of psychiatric disorders in children and adolescents: focus on guidelines for the primary care practitioner. Drugs 51, 750-759.

Chatziioannou AF, Cherry SR, Shao Y, Silverman RW, Meadors K, Farquhar TH, Pedarsani M, and Phelps ME (1999) Performance evaluation of microPET: A high-resolution lutetium oxyorthosilicate PET scanner for animal imaging. Journal of Nuclear Medicine 40, 1164-1175.

Chiueh CC and Kopin IJ (1978) Centrally mediated release by cocaine of endogenous epinephrine and norepinephrine from the sympathoadrenal medullary system of unanesthetized rats. Journal of Pharmacology and Experimental Therapy 205, 148-154.

Christman DR, Finn RD, Karlstrom KI and Wolf AP (1975) The production of ultra high activity ${ }^{11} \mathrm{C}$-labeled hydrogen cyanide, carbon dioxide, carbon monoxide, and methane via the ${ }^{14} \mathrm{~N}(\mathrm{p}, \alpha){ }^{11} \mathrm{C}$ reaction. XV. International Journal of Applied Radiation Isotopes 26, 435442.

Cohen G and Kesler N (1999) Monoamine oxidase and mitochondrial respiration. Journal of Neurochemistry 73, 2310-2315. 
Dachis CA and Gold MS (1985) New concepts in cocaine addiction: the dopamine depletion hypothesis. Neuroscience and Biobehavioral Review 9, 469-477.

Dewey SL, Brodie JD, Gerasimov M, Horan B, Gardner EL and Ashby CR, Jr. (1999) A pharmacologic strategy for the treatment of nicotine addiction. Synapse, 31, 76-86.

Ding Y-S, Fowler JS, Gatley SJ, Dewey SL, and Wolf AP (1991) Synthesis of high specific activity $(+)$ and $(-)-6-\left[{ }^{18} \mathrm{~F}\right]$ fluoronorepinephrine via the nucleophilic aromatic substitution reaction. Journal of Medicinal Chemistry 34, 767-771.

Ding Y-S, Sugano Y, Fowler JS and Salata C (1994) Synthesis of the racemate and individual enantiomers of $\left[{ }^{11} \mathrm{C}\right]$ methylphenidate for studying presynaptic dopaminergic neurons and positron emission tomography. Journal of Labelled Compounds and Radiopharmaceuticals 34, 989-997.

Ding Y-S, Shiue C-Y, Fowler JS, Wolf AP, and Plenevaux A (1990) No-carrier-added (NCA) aryl $\left[{ }^{18} \mathrm{~F}\right]$ fluorides via the nucleophilic aromatic substitution of electron rich aromatic rings. Journal of Fluorine Chemistry 48, 189-205.

Ding Y-S and Fowler JS (1996) ${ }^{18} \mathrm{~F}$ - Labeled tracers for positron emission tomography studies in the neurosciences. In Biomedical Frontiers of Fluorine Chemistry, Chapter 23, 328-343.

Ding Y-S, Fowler JS, Volkow ND, Dewey SL, Wang G-J, Gatley J, Logan J, and Pappas N (1997) Chiral drugs: Comparison of the pharmacokinetics of $\left[{ }^{11} \mathrm{C}\right] d$-threo and 1-threomethylphenidate in the human and baboon brain. Psychopharmacology, 131, 71-78.

Ding Y-S, Logan J, Bermel R, Garza V, Rice O, Fowler JS, and Volkow ND (2000a) Dopamine receptor-mediated regulation of striatal cholinergic activity: PET studies with $\left[{ }^{18} \mathrm{~F}\right]$ norchlorofluoroepibatidine Journal of Neurochemistry 74, 1514-1521.

Ding Y-S, Volkow ND, Logan J, Garza V, Pappas N, King P, and Fowler JS (2000b) Occupancy of brain nicotinic acetylcholine receptors by nicotine doses equivalent to those obtained when smoking a cigarette. Synapse 35, 234-237. 
Ding Y-S, Liu N, Wang T, Marecek J, Garza V, Ojima I, and Fowler JS (2000c) Synthesis and evlauation of 6-[ $\left.{ }^{18} \mathrm{~F}\right]$ fluoro-3-(2(S)-azetidinylmethoxy)pyridine as a PET tracer for nicotinic acetylcholine receptors. Nuclear Medicine and Biology 27, 381-389.

Domino EF (1995) Brain Imaging of Nicotine and Tobacco Smoking. NPP Books, Ann Arbor, Michigan.

Dougherty DD, Bonab AA, Spencer TJ, Rauch SL, Madras BK, and Fischman AJ (1999) Dopamine transporter density in patients with attention deficit hyperactivity disorder. Lancet 354, 2132-2133.

Farde L, Ehrin E, Eriksson L, Greitz T, Hall H, Hedström CG, Litton JE, and Sedvall G (1985) Substituted benzamides as ligands for visualization of dopamine receptor binding in the human brain by positron emission tomography. Proceedings of the National Academy of Science USA, 82, 3863-3867.

Firnau G, Garnett ES, Chirakal R, Sood S, Nahmias C, and Schrobilgen G. (1986) [ ${ }^{18}$ F]Fluoro-LDOPA for the in vivo study of intracerebral dopamine Applied Radiation Isotopes 37, 669-675.

Firouzbakht ML, Schlyer DJ, and Fowler JS (1999) Cryogenic target design considerations for the production of $\left[{ }^{18} \mathrm{~F}\right]$ fluoride from enriched $\left[{ }^{18} \mathrm{O}\right]$ carbon dioxide. Nuclear Medicine and Biology 26, 749-753.

Fowler JS, MacGregor RR, Wolf AP, Arnett CD, Dewey SL, Schlyer D, Christman D, Logan J, Smith M, Sachs H, Aquilonius SM, Bjurling P, Halldin C, Hartwig P, Leenders KL, Lundquist H, Oreland L, Stalnacke C-G, and Langström B (1987) Mapping human brain monoamine oxidase $\mathrm{A}$ and $\mathrm{B}$ with ${ }^{11} \mathrm{C}$-suicide inactivators and positron emission tomography. Science, 235, 481-485.

Fowler JS, Wolf AP, MacGregor RR, Dewey SL, Logan J, Schlyer DJ, and Langstrom B (1988) Mechanistic positron emission tomography studies. Demonstration of a deuterium isotope effect in the MAO catalyzed binding of $\left[{ }^{11} \mathrm{C}\right] \mathrm{L}$-deprenyl in living baboon brain. Journal of Neurochemistry 51, 1524-1534. 
Fowler JS, Volkow ND, Wolf AP, Dewey SL, Schlyer DJ, MacGregor RR, Hitzemann R, Logan J, Bendriem B, Gatley SJ, and Christman D (1989) Mapping cocaine binding in human and baboon brain in vivo. Synapse, 4, 371-377.

Fowler JS, Ding Y-S, Volkow ND, Martin T, MacGregor RR, Dewey S, King P, Pappas N, Alexoff D, Shea C, Gatley SJ, Schlyer DJ, and Wolf AP (1994) PET studies of cocaine inhibition of the myocardial norepinephrine uptake. Synapse 16, 312-317.

Fowler JS, Wang G-J, Logan J, Xie S, Volkow ND, MacGregor RR, Schlyer DJ, Pappas N, Alexoff DL, Patlak C, and Wolf AP (1995) Selective reduction of radiotracer trapping by deuterium substitution: comparison of $\left[{ }^{11} \mathrm{C}\right] \mathrm{L}$-deprenyl and $\left[{ }^{11} \mathrm{C}\right] \mathrm{L}$-deprenyl- $\mathrm{D}_{2}$ for MAO B mapping. Journal of Nuclear Medicine 36, 1255-1262.

Fowler JS, Volkow ND, Wang G-J, Pappas N, Logan J, Shea C, Alexoff DL, MacGregor RR, Schyler DJ, Wolf AP, and Zelzukova I (1996a) Brain Monoamine Oxidase A Inhibition in Cigarette Smokers. Proceedings of the National Academy of Science USA 93, 1406514069.

Fowler JS, Wang G-J, Volkow ND, Pappas N, Logan J, MacGregor RR., Alexoff D, Wolf AP, Warner D, Cilento R, and Zezulkova I (1996b) Inhibition of monoamine oxidase B in the brains of smokers. Nature 379, 733-736.

Fowler JS and Wolf AP (1997) Working against time: Rapid radiotracer synthesis and imaging the human brain. Accounts of Chemical Research 30,181-188

Fowler JS and Volkow ND (1998a) PET imaging studies in drug abuse. Clinical Toxicology, 36, $163-174$.

Fowler JS, Volkow ND, Logan J, Pappas N, King P, MacGregor R, Shea C, Garza V, and Gatley SJ (1998b) An acute dose of nicotine does not inhibit MAO B in baboon brain in vivo. Life Science 63(2), PL 19-23.

Fowler JS, Volkow ND, Wang G-J, Ding Y-S, and Dewey SL (1999a) PET and drug research and development. Journal of Nuclear Medicine., 40, 1154-1163. 
Fowler JS, Wang G-J, Volkow ND, Franceschi D, Logan J, Pappas N, Shea C, MacGregor RR, and Garza V (1999b) Smoking a single cigarette does not produce a measurable reduction in brain MAO B in non-smokers. Nicotine and Tobacco Research 1, 325-329.

Fowler JS, Wang G-J, Volkow ND, Franceschi D, Logan J, Pappas N, Shea C, MacGregor RR, and Garza V. (2000) Maintenance of MAO B inhibition in smokers after a 12-hour cigarette abstinence. American Journal of Psychiatry.

Gatley SJ, MacGregor RR, Fowler JS, Wolf AP, Dewey SL, and Schlyer DJ (1990) Rapid stereoselective hydrolysis of (+)-cocaine in baboon plasma prevents its uptake in the brain: Implications for behavioral studies. Journal of Neurochemistry 54, 720-723. Gatley SJ. (1991) Activities of the enantiomers of cocaine and some related compounds as substrates and inhibitors of plasma butyrylcholinesterase. Biochemical Pharmacology 41, 1249-1254.

Gatley SJ, Yu D-W, Fowler JS, MacGregor RR, Schlyer DJ, Dewey SL, Wolf AP, Martin T, Shea CE, and Volkow ND (1994) Benzoylecgonine, and C-11 and F-18 4'-fluorococaine, to probe the extent to which $\mathrm{C}-11$ cocaine metabolites contribute to PET images of the baboon brain. Journal of Neurochemistry 62, 1154-1162.

Glassman AH, Helzer JE, Covey LS, Cottler LB, Stetner F, Tipp JE, and Johnson J (1990) Smoking, smoking cessation, and major depression. Journal of the American Medical Association 264,1546-1549.

Halldin C, Burling P, Stalnacke C-G, Jossan SS, Oreland L, and Langstrom B (1989) ${ }^{11}$ CLabeling of dimethylphenethylamine in two different positions and biodistribution studies. Applied_Radiation and Isotopes 40, 557-560.

Hamacher K, Coenen HH, Stocklin G (1986) Efficient stereospecific synthesis of NCA 2-[18F]fluoro-2-deoxy-D-glucose using aminopolyether supported direct nucleophilic substitution. Journal of Nuclear Medicine 27, 235-238.

Henningfield JE, Clayton R, and Pollen W (1990) Involvement of tobacco in alcoholism and illicit drug use. British Journal of Addiction 85, 279-292. 
Hughes JR, Hatsukami DK, Mitchell JE, and Dahlgren LA (1986) Prevalence of smoking among psychiatric outpatients._American Journal of Psychiatry 143, 993-997.

Ido T,Wan C-N, Casella V, Fowler JS, Wolf AP, Reivich M, and Kuhl DE (1978) Labeled 2deoxy-D-glucose analogs. 18F-labeled 2-deoxy-2-fluoro-D-glucose, 2-deoxy-2-fluoro-Dmannose and C-14-2-deoxy-2-fluoro-D-glucose. Journal of Labelled Compounds and Radiopharmaceuticals 14, 175-182.

Jeavons AP, Chandler RA, and Dettmar CAR (1999) A 3D HIDAC-PET camera with submillimetre resolution for imaging small animals. IEEE Transactions on Nuclear Science 46, $468-473$.

Johanson CE and Shuster CR (1975) A choice procedure for drug reinforcers: cocaine and methylphenidate in the rhesus monkey. Journal of Pharmacology and Experimental Therapy 193, 676-688.

Khalil AA, Steyn S, and Castagnoli N (2000) Isolation and characterization of a monoamine oxidase inhibitor from tobacco leaves. Chemical Research In Toxicology 13, 31-35. Kilbourn MR (1990) Fluorine-18 Labeling of Radiopharmaceuticals. National Academy Press, Washington D. C.

Kloner RA, Hale RS, Alker K, and Rezkalla S (1992) The effects of acute and chronic cocaine use on the heart. Circulation 85, 407-419.

Kloss MW, Rosen GM, and and Rauckman EJ (1984) Cocaine-mediated hepatotoxicity: A critical review. Biochemical Pharmacology 33, 169.

Krause K, Dresel SH, Krause J, Kung HF, and Tatsch K (2000) Increased striatal dopamine transporter in adult patients with attention deficit hyperactivity disorder: effects of methylphenidate as measured by single photon emission computed tomography. Neuroscience Letter 285, 107-110.

Lambrecht RM and Wolf AP (1973) Cyclotron and short-lived halogen isotopes for radiopharmaceutical applications. Proceedings of the IAEA Symposium "Radiopharmaceuticals and Labelled Compounds", I, 275-290. 
Langstrom $B$ and Lundqvist $\mathrm{H}$ The preparation of ${ }^{11} \mathrm{C}$-methyl iodide and its use in the synthesis of ${ }^{11} \mathrm{C}$-methyl-L-methionine (1976). International Journal of Applied Radiation and Isotopes 27, 357-363.

Larsen P, Ulin J, and Dahlstrom K (1995) A new method for production of ${ }^{11} \mathrm{C}$-labeled methyl iodide from ${ }^{11} \mathrm{C}$-methane. Journal of Labelled Compounds and Radiopharmaceuticals. 37, 73-75.

Leshner AI (1997) Addiction is a brain disease and it matters. Science 278, 45-47.

Lidberg L, Modin I, Oreland L, Tuck JR, and Gillner A (1985) Platelet monoamine oxidase activity and psychopathy. Psychiatry'Research 4, 339-43.

Link JM, Clark JC, Larsen P, and Krohn K (1995) Production of $\left[{ }^{11} \mathrm{C}\right]$ methyl iodide by reaction of ${ }^{11} \mathrm{CH}_{4}$ with $\mathrm{I}_{2}$. Journal of Labelled Compounds and Radiopharmaceuticals. 37, 76-78.

Logan J, Fowler JS, Volkow ND, Wolf AP, Dewey SL, Schlyer DJ, MacGregor RR, Hitzemann R, Bendriem B, Gatley SJ, and Christman DR (1990) Graphical analysis of reversible radioligand binding from time-activity measurements applied to $\left[\mathrm{N}^{1}{ }^{11} \mathrm{C}-\right.$ methyl $]-(-)-$ cocaine PET studies in human subjects. Journal of Cerebral Blood Flow and Metabolism 10, 740-747.

Logan J, Fowler JS, Volkow ND, Wang G-J, MacGregor RR, and Shea C (2000) Reproducibility of repeated measures of deuterium substituted $\left[{ }^{11} \mathrm{C}\right] \mathrm{L}$-deprenyl $\left(\left[{ }^{11} \mathrm{C}\right] \mathrm{L}\right.$-deprenyl-D2) binding in the human brain. Nuclear Medicine and Biology_27, 43-49.

Madras BK, Spealman RD, Fahey MA, Neumeyer JL, Saha JK, and Milius RA (1989) Cocaine receptors labeled by $\left[{ }^{3} \mathrm{H}\right] 2 \beta$-carbomethoxy-3 $\beta$-(4-fluorophenyl)tropane. Molecular Pharmacology 36, 518-524.

Melon PG, Ngyyen N, DeGrado T, Manger TJ, Wieldand DM, and Schwaiger M (1994) Imaging of cardiac neuronal function after cocaine exposure using carbon- 11 hydroxyephedrine and positron emission tomography. Journal of the American College of Cardiology 23, 1693-1699. 
Melon PG, Boyd CJ, McVey S, Manger TJ, Wieland DM, and Schwaiger M (1997) Effects of active cocaine use of cardiac sympathetic neuronal function assessed by carbon-11 hydorxyephedrine. Journal of Nuclear Medicine 38, 451-456.

Mintun MA, Raichle ME, Kilbourn MR, Wooten GF, and Welch MJ (1984) A quantitative model for the in vivo assessment of drug binding sites with positron emission tomography. Annals of Neurology 15, 217-227.

Misra AL, Nayak PK, Bloch R, and Mule SJ (1975) Estimation and disposition of $\left[{ }^{3} \mathrm{H}\right]$ benzoylecgonine and pharmacological activity of some cocaine metabolites. Journal of Pharmaceutical Pharmacology 27, 784-786.

Morens DM, Grandinetti A, Reed D, White LR, and Ross GW (1995) Cigarette smoking and protection from Parkinson's disease: false association or ctiological clue. Neurology 45, 1041-1051.

National Institute on Drug Abuse, Community Epidemiology Work Group (CEWG) (1995) Epidemiologic Trends in Drug Abuse. DHHS Pub. No. (NIH) 95-3988.

Norman TR, Chamberlain KG, and French MA (1987) Platelet monoamine oxidase: low activity in cigarette smokers. Psychiatry Research 20, 199-205.

O'Brien CP (1997) A range of research-based pharmacotherapies for addiction. Science 278, 6670.

Oreland L, Fowler CJ, and Schalling D (1981) Low platelet monoamine oxidase activity in cigarette smokers. Life Science 29, 2511-2518.

Parran TV and Jasinski DR (1991) Intravenous methylphenidate abuse: prototype for prescription drug abuse. Archives of Internal Medicine 151,781-783.

Patlak C, Fenstermacher JD, and Blasberg RG (1983) Graphical evaluation of blood-to-brain transfer constants from multiple time-activity data. Journal of Cerebral Blood Flow and Metabolism 3, 1-7.

Patrick KS, Caldwell RW, Ferris RM, and Breese GR (1987) Pharmacology of the enantiomers of threo-methylphenidate. J Pharmacol Exp Ther, 241, 152-8 
Polkis A, Maginn D, and Barr JL (1987) Tissue disposition of cocaine in man: A report of five fatal poisonings. Forensic Science International 33, 83-88.

Ritchie JM and Greene NM (1990) Local anesthetics. Chapter 15. The Pharmacological Basis of Therapeutics (A. Gilman and L. S. Goodman, eds.) Pergamon Press, New York, p 311. Ritz MC, Lamb RJ, Goldberg SR, and Kuhar MJ (1987) Cocaine receptors on dopamine transporters are related to self-administration of cocaine. Science 237, 1219-1223. Ruth TJ and Wolf AP (1979) Absolute Cross Sections for the Production of $18 \mathrm{~F}$ via the ${ }^{18} \mathrm{O}(\mathrm{p}, \mathrm{n})^{18}$ F Reaction. Radiochimica Acta 26, 21-24.

Scheffel U, Pogun S, Stathis M, Boja JW, and Kuhar MJ (1991) In vivo labeling of cocaine binding sites on dopamine transporters with $\left[{ }^{3} \mathrm{H}\right]$ WIN 35,428. Journal of Pharmacology and Experimental Therapeutics 257, 954-958.

Schwartz WJ, Sharp FR, Gunn RH, and Evarts EV (1976) Lesions of ascending dopaminertic pathways decrease forebrain glucose uptake. Nature 251, 155-157.

Shiue C-Y, Fowler JS, Wolf AP, Watanabe M, and Arnett CD (1985) Synthesis and specific activity determinations of no-carrier-added (NCA) 18 F-labeled butyrophenone neuroleptics - benperidol, haloperidol, spiroperidol and pipamperone. Journal of Nuclear Medicine, 26, 181-186.

Sihver W, Nordberg A, Langstrom B, Mukhin AG, Koren AO, Kimes AS, and London ED (2000) Development of ligands for in vivo imaging of cerebral nicotinic receptors. Behavioral Brain Research 113, 143-157.

Simpson GM, Shih JC, Chen K, Flowers C, Kumazawa T and Spring B (1999) Schizophrenia, monoamine oxidase and cigarette smoking. Neuropsychopharmacology 20, 392-394.

Singer T (1995) Monoamine oxidases: old friends hold many surprises. FASEB J. 9, 605-610. Spealman RD, Kelleher RT, and Goldberg SR (1983) Stereoselective effects of cocaine and a phenyltropane analog. Journal of Pharmacology and Experimental Therapy 225, 509514. 
Stein EA, Pankiewicz J, Harsch HH, Cho J-K, Fuller S, Hopffmann RG, Hawkins M, Rao SM, Bandetti PA, and Bloom AS (1998) Nicotine-induced cortical activation in the human brain: a functional MRI study. American Journal of Psychiatry 155, 1009-1015.

Telang FW, Volkow ND, Levy A, Logan J, Fowler JS, Felder C, Wong C, and Wang G-J. (1999)

Distribution of tracer levels of cocaine in the human brain as assessed with averaged $\left[{ }^{11} \mathrm{C}\right]$ cocaine images. Synapse 31, 290-296.

Volkow ND, Fowler JS, Wolf AP, Schlyer D, Shiue C-Y, Dewey SL, Alpert R, Logan J, Christman D, Bendriem B, Hitzemann R, and Henn F (1990) Effects of chronic cocaine abuse on postsynaptic dopamine receptors. American Journal of Psychiatry 147, 719-724.

Volkow ND, Fowler JS, Wolf AP, Hitzemann R, Dewey SL, Bendriem B, Alpert R and Hoff A (1991) Changes in brain glucose metabolism in cocaine dependence and withdrawal. American Journal of Psychiatry 148, 621-626.

Volkow ND, Hitzemann R, Wang G-J, Fowler JS, Wolf AP, and Dewey SL (1992a) Long-term frontal brain metabolic changes in cocaine abusers. Synapse 11, 184-190.

Volkow ND, Fowler JS, Wolf AP, Wang G-J, Logan J, MacGregor R, Dewey SL, Schlyer D, and Hitzemann R. (1992b) Distribution and kinetics of ${ }^{11} \mathrm{C}$-cocaine in the human body measured with PET. Journal of Nuclear Medicine 33, 521-525.

Volkow ND, Fowler JS, Wang G-J, Hitzemann R, Logan J, Schlyer DJ, Dewey S, and Wolf AP (1993) Decreased Dopamine $D_{2}$ Receptor Availability is Associated with Reduced Frontal Metabolism in Cocaine Abusers. Synapse, 14, 169-177.

Volkow ND, Wang G-J, Fowler JS, Logan J, Schlyer D, Hitzemann R, Lieberman J, Angrist B, Pappas N, MacGregor R, Burr G, Cooper T and Wolf AP (1994) Imaging Endogenous Dopamine Competition with [11 C]Raclopride in the Human Brain. Synapse, 16, 255-262. Volkow ND, Ding Y-S, Fowler JS, Wang G-J, Logan J, Gatley SJ, Dewey S, Ashby C, Liebertman J, and Wolf AP (1995) Is methylphenidate like cocaine? Studies on their 
pharmacokinetics and distribution in human brain. Archives of General Psychiatry 152, 456-463.

Volkow ND, Wang G-J, and Fowler JS, Gatley SJ, Ding Y-S, Logan J, Hitzemann R and Lieberman J (1996) Relationship between psychostimulant induced high and dopamine transporter occupancy. Proceedings of the National Academy of Science USA 93, 1038810392.

Volkow ND, Wang, G-J, Fischman M, Foltin R, Fowler JS, Abumrad NN, Vitkun S, Logan J, Gatley SJ, Pappas N, Hitzemann R, and Shea CE (1997a) Relationship between subjective effects of cocaine and dopamine transporter occupancy. Nature 386, 827-830.

Volkow ND, Wang G-J, Fowler JS, Logan J, Gatley SJ, Hitzemann R, Chen AD, Dewey SL, and Pappas N (1997b) Decreased striatal dopaminergic responsiveness in detoxified cocainedependent subjects. Nature, 386, 830-833.

Volkow ND, Wang G-J, Fowler JS, Gatley SJ, Logan J, Ding Y-S, Hitzemann R, and Pappas N (1998) Dopamine transporter occupancies in the human brain induced by therapeutic doses of oral methylphenidate. American Journal of Psychiatry 155, 1325-1331.

Volkow ND, Wang G-J, Fowler JS, Logan J, Gatley SJ, Wong C, Hitzemann RJ, and Pappas N (1999a) Reinforcing effects of psychostimulants in humans are associated with increases in brain dopamine and occupancy of D2 receptors. Journal of Pharmacology and Experimental Therapeutics 291, 409-415.

Volkow ND, Wang GJ, Fowler JS, Logan J, Gatley SJ, Gifford A, Hitzemann R, Ding Y-S, and Pappas N (1999b) Prediction of reinforcing responses to psychostimulants in humans by brain dopamine D2. American Journal of Psychiatry 156, 1440-1443.

Volkow ND and Fowler JS (2000) Addiction, a disease of compulsion and drive: Involvement of the orbitopfrontal cortex. Cerebral Cortex 10, 318-325.

Volkow ND, Wang G-J, Fowler JS, Logan J, Gerasimov M, Maynard L, Ding Y-S, Gatley SJ, Gifford A, and Franceschi D Therapeutic doses of oral methylphenidate significantly increase extracellular dopamine in the human brain. Journal of Neuroscience, in press. 

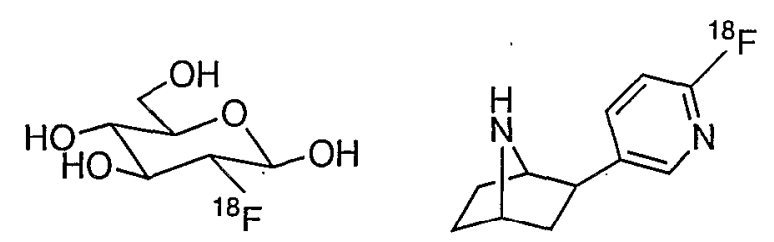<smiles>[2H]C([2H])(C#C)N(C)[C@@H](C)Cc1ccccc1</smiles><smiles>C#CCN(C)CCCOc1ccc(Cl)cc1Cl</smiles>
${ }^{18} \mathrm{FDG}$ norchloro- $\left[{ }^{18} \mathrm{~F}\right]$ fluoroepibatidine $\left[{ }^{11} \mathrm{C}\right] \mathrm{L}$-deprenyl-D2

$\left[{ }^{11}\right.$ C]clorgyline

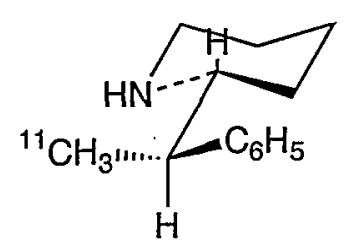

$\left[{ }^{11} \mathrm{C}\right] d$-threo-methylphenidate<smiles>CCOC(=O)OC1CC2CCC1N([14CH3])C2C(=O)OCC</smiles>

$\left[{ }^{11} \mathrm{C}\right]$ cocaine<smiles>CCN1CCC[C@H]1CNC(=O)c1c(O)c(Cl)cc(Cl)c1OC</smiles>

$\left[{ }^{11} \mathrm{C}\right]-\mathrm{S}-(-)$-raclopride 


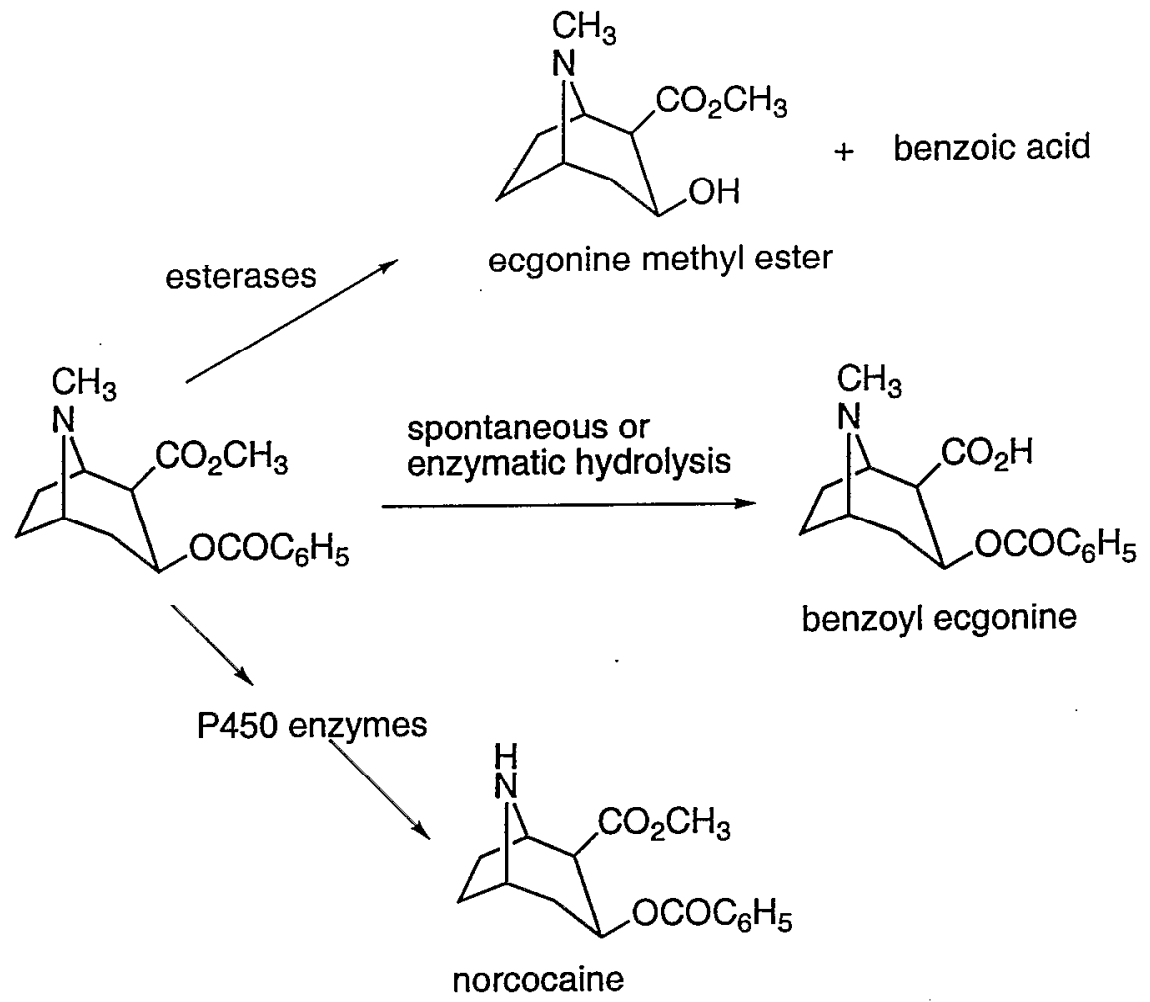

Figure 2 


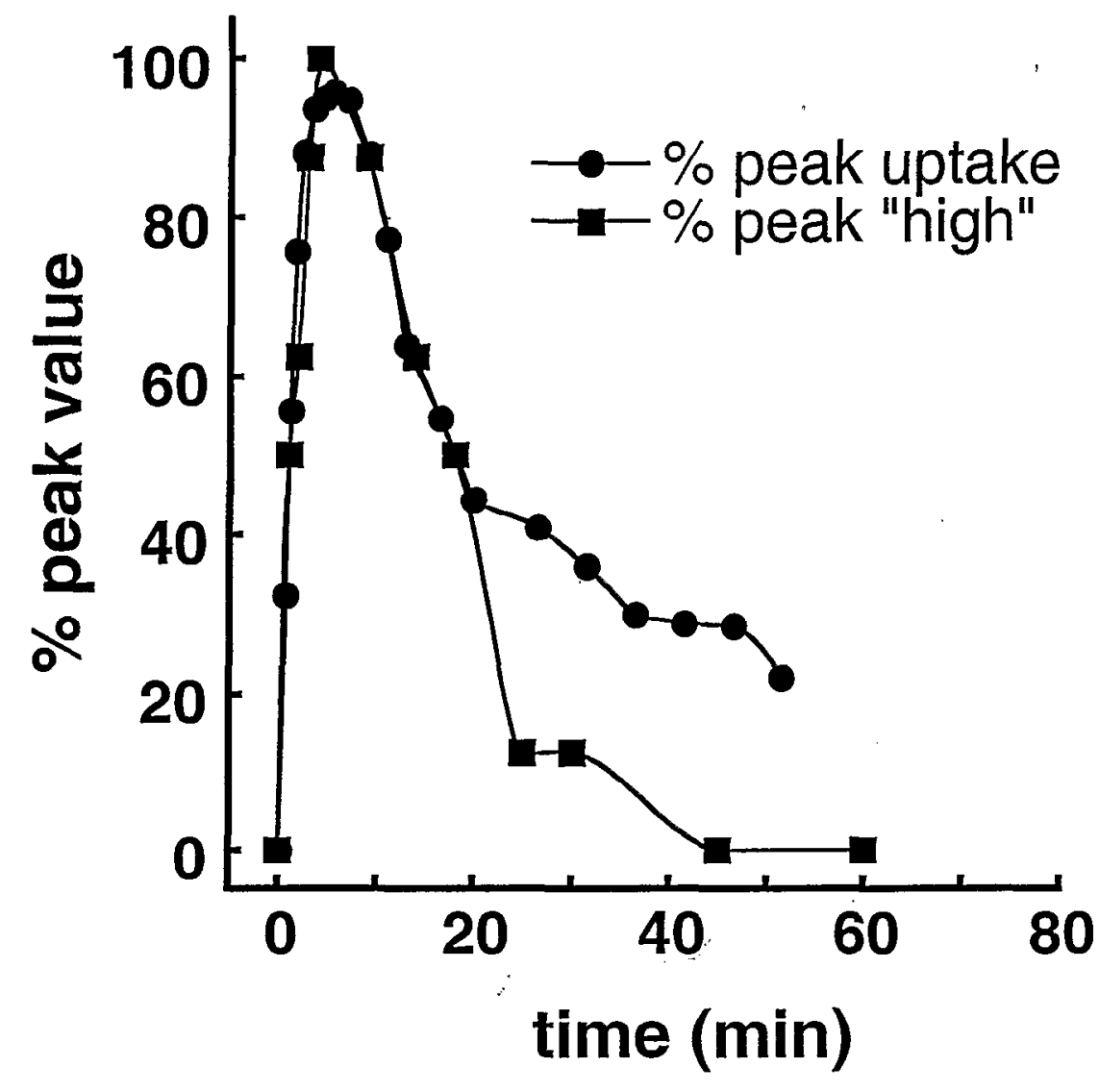

Figure 3 


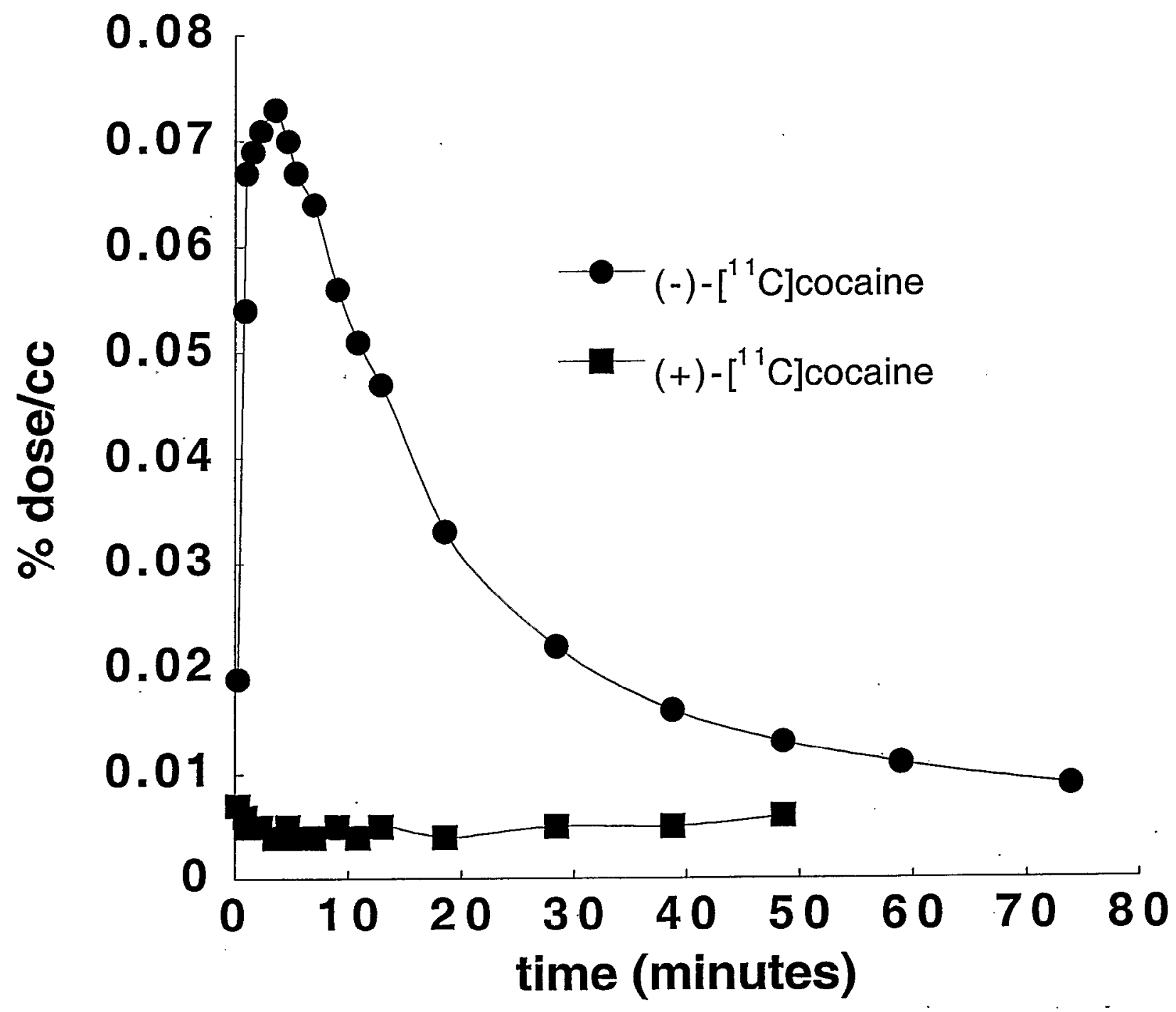

Figure 4 

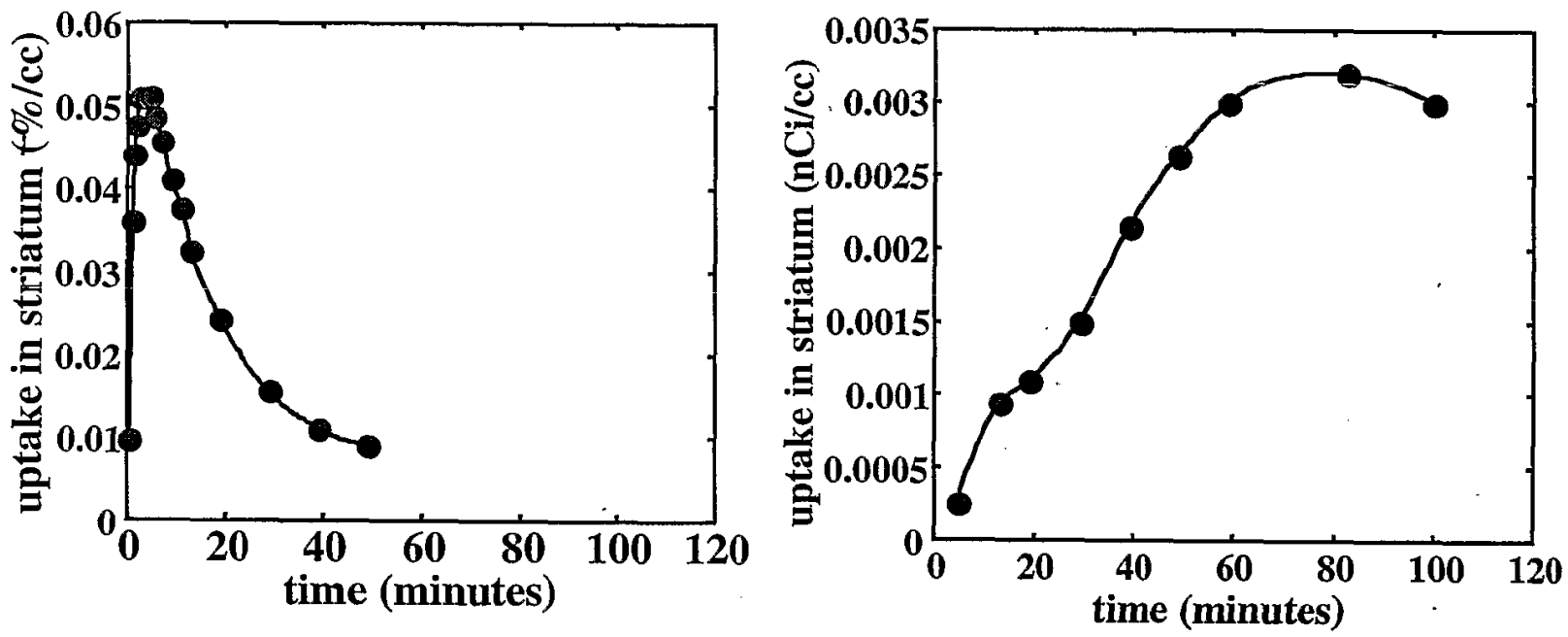

Figure 5 


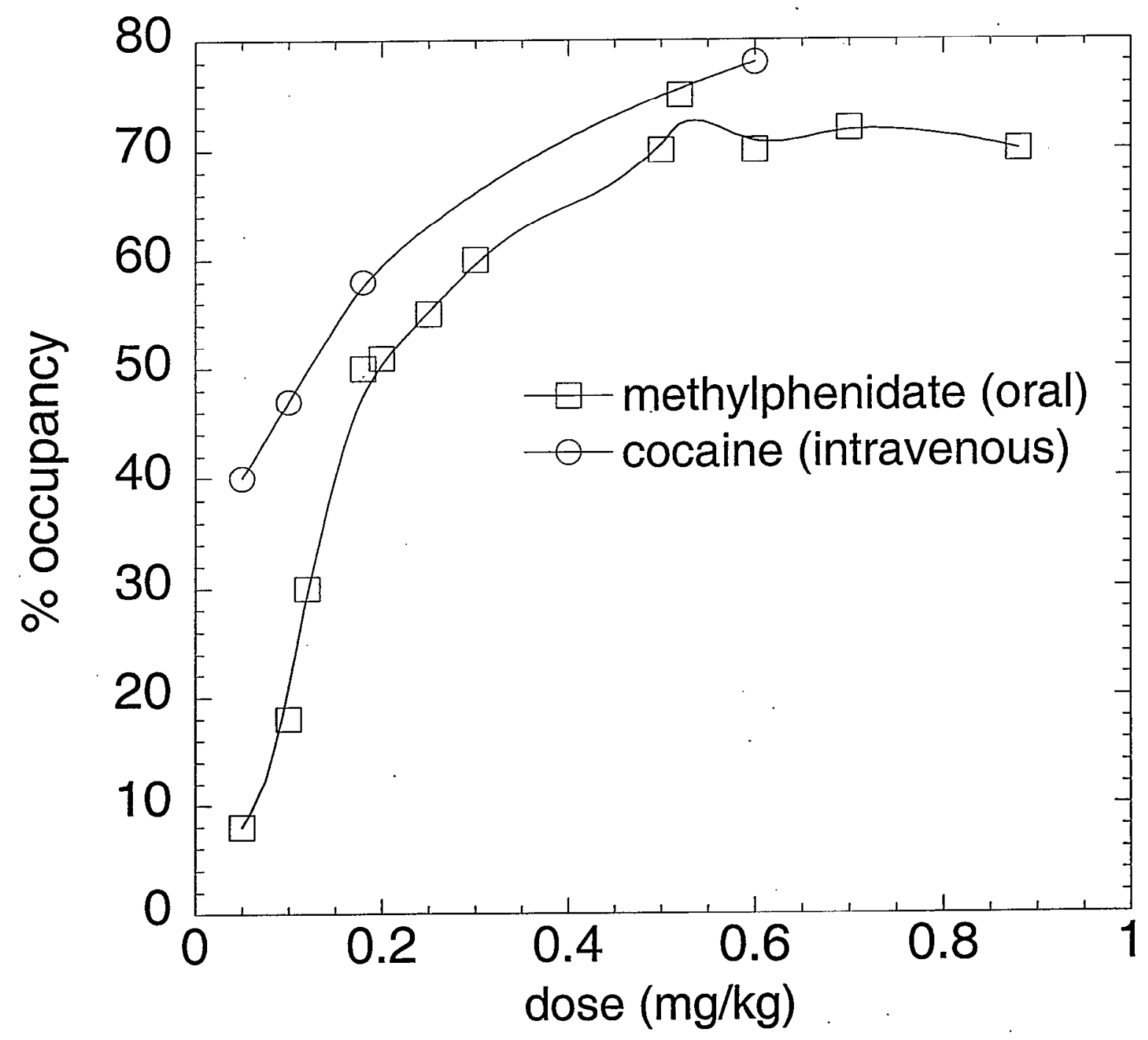

Figure 6 

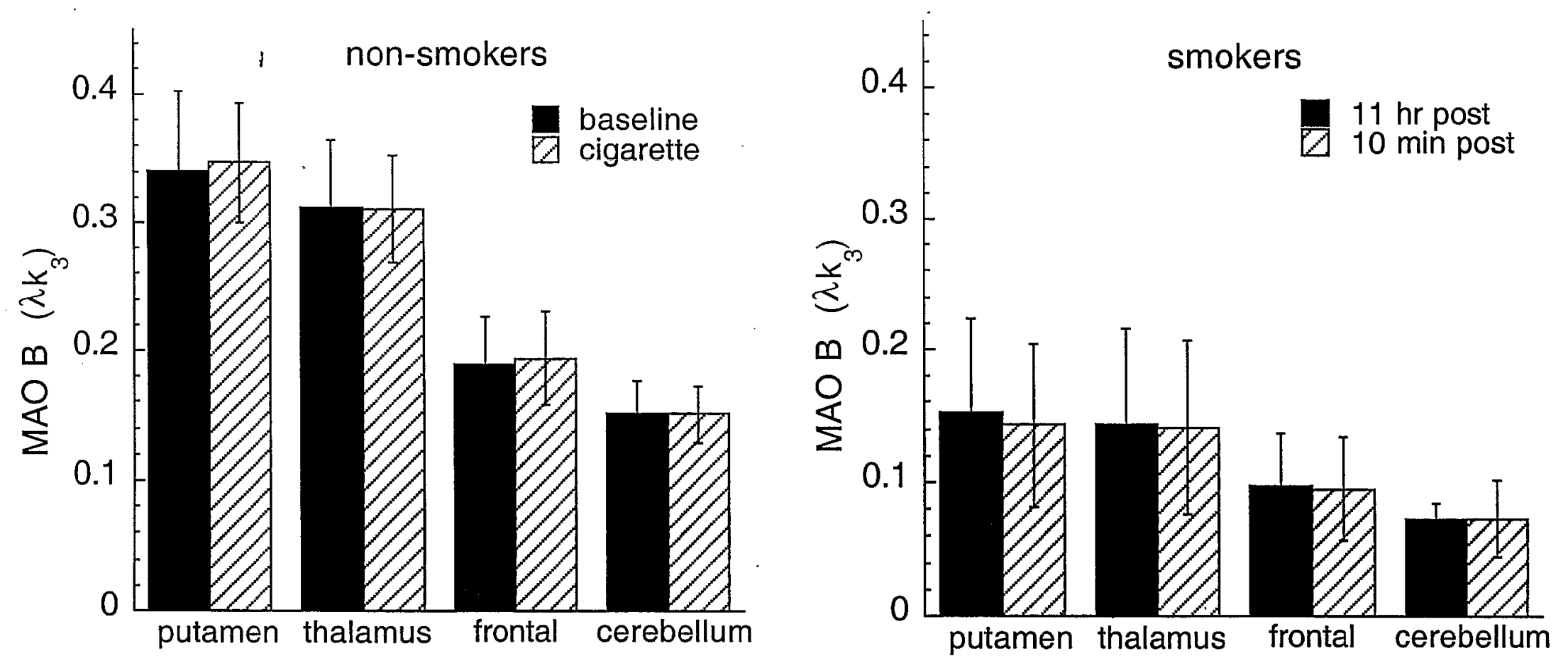


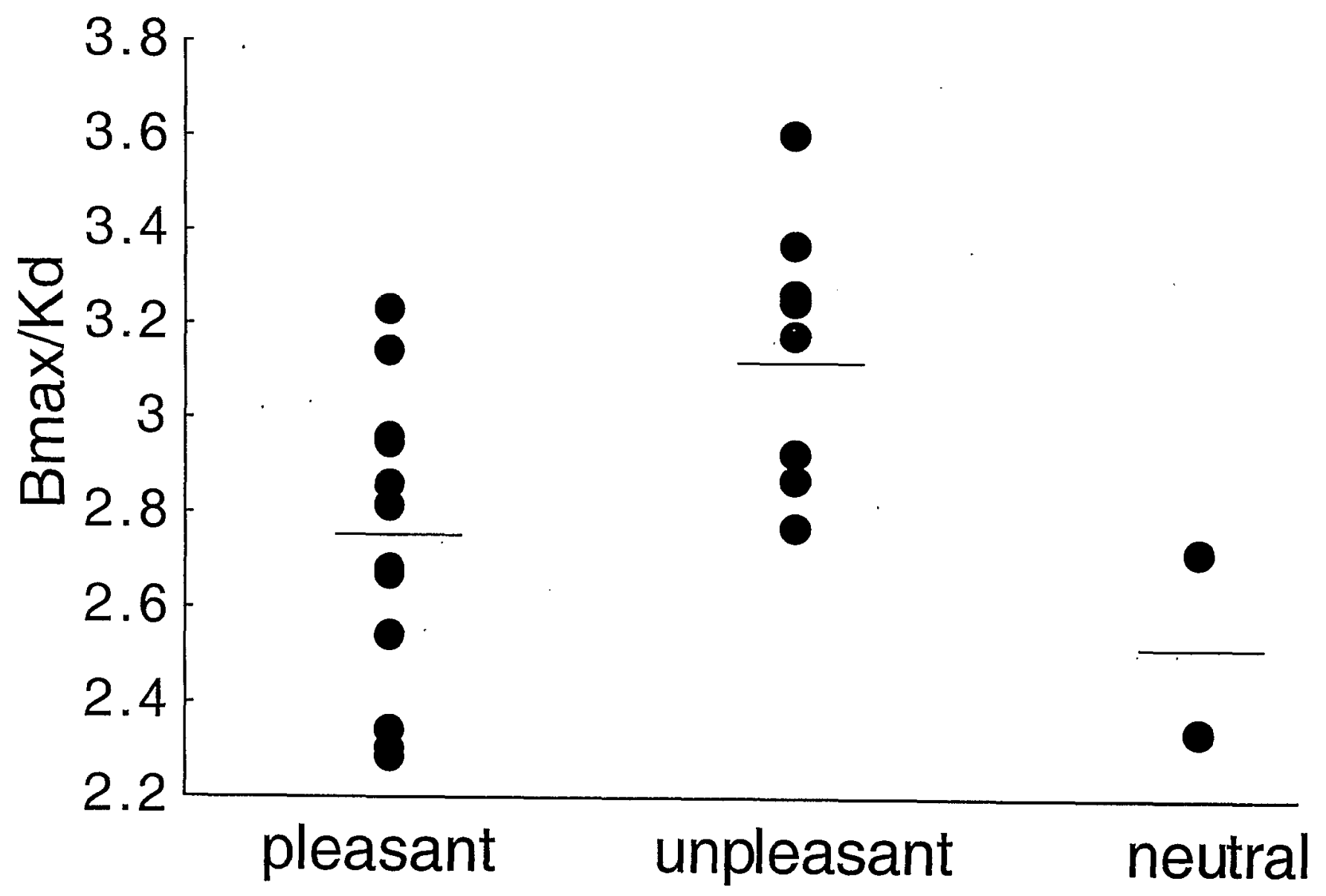

